\title{
The clinical, genetic and dystrophin characteristics of Becker muscular dystrophy
}

\section{Natural history}

\section{K.M. D. Bushby ${ }^{1}$, D. Gardner-Medwin ${ }^{2}$}

${ }^{1}$ Department of Human Genetics, 19/20 Claremont Place, Newcastle upon Tyne NE2 4AA, UK

${ }^{2}$ Children's Department, Newcastle General Hospital, Westgate Road, Newcastle upon Tyne, UK

J Neurol (1993) 240:98-104

On page 103 , the mutation rate for the dystrophin gene as a whole was quoted as $2.63 \times 10^{-5}$. This should have read $6.53 \times 10^{-5}$. 